\title{
FINTAN MAC BÓCHRA: IRISH SYNTHETIC HISTORY REVISITED ${ }^{1}$
}

\author{
GRIGORY BONDARENKO
}

\section{Introduction. Fintan's name and his role in Airne Fíngein}

Fintan mac Bóchra is one of the characters in Early Irish tradition who act as the self-sufficient centre of their own mythological situation. He figures prominently as a plot-making protagonist in a number of Irish texts serving as a main character of a particular tale or a plot. Celtic scholars have extensively discussed Fintan, and have expressed many opposing views concerning him. Starting with the most influential opinions: he has been taken to be 'the Otherworld god' (not surprisingly: O'Rahilly 1946: 319 ), as a primordial human being of Irish tradition (Guyonvarc'h \& Le Roux 2005: 322$)^{2}$ or as a synthetic apocryphal being, the product of monastic learning (McCone 1991: 199). In my view it would not be sufficient merely to say that he combines all these features before a proper reassessment of this character.

Let us start with the name the meaning of which was possibly significant for the audience at a certain period. T. F. O'Rahilly in his stimulating discussion of Fintan and related matters gives two etymologies of his name - one K. Meyer's and one of his own. K. Meyer suggested that the name Finten (later Fintan) is derived from common Celtic *Vindo-senos 'weiss(haarig) und alt' (through Find-shen) (Meyer 1912: 791) ('the white ancient' in O'Rahilly's interpretation). Meyer considered this name to be a dvandva compound. I have to note that to my knowledge the early Old Irish form Finten does not occur in connection with the character discussed (it also has to be stressed that Finten/Fintan is

\footnotetext{
${ }^{1}$ I am grateful to John Carey and Iwan Wmffre for their suggestions and corrections to this article, and especially to Dr Carey's convincing and strong arguments in favour of Fintan's synthetic and complex nature. Nevertheless I am solely responsible for all misrepresentations and faults left in the text.

${ }^{2}$ Guyonvarc'h \& Le Roux's definition of a 'primordial man' is important for our subsequent discussion: 'l'expression s'applique à un ancêtre ou un archetype qui, analogue en cela aux patriarches bibliques, est le premier représentant d'une race, d'un peuple ou d'une classe sociale. Les hommes primordiaux... ont permis la transmission du savoir originel' (2005: 398).

${ }^{3}$ The name is likely to be attested in inverted form in the name of the great sow of Welsh tradition, Henwen < Senuvindá. The same name occurs several times as that of a man in the form Henwyn (Bromwich 2006: n. 26, 398).
} 
a well-known personal name in early Christian Ireland). Fintan's old age (*-senos) semantically corresponds to his function as the oldest man in Ireland. This etymology is widely accepted by Celtic scholars. Nevertheless O'Rahilly gives his own variant, noting that Vindo- + sh gives Find in Findabair and *Vindo-senos might have given *Findan (*Finnan) rather than Fintan. He derives the name from *Vindo-tenos, "of which the second component may be a form of tene or ten, "fire"" (O'Rahilly 1946: 319). O'Rahilly's arguments were followed by $\mathrm{H}$. Meroney's remark in his review of J. Vendryes' edition of Airne Fingein, when he proposed to view the second element of the name as tan 'time' (Meroney 1953-58: 247; Meroney here followed D'Arbois de Jubainville's hypothesis who suggested a meaning 'white time', Mac Neill 1981: 33). The white colour of Fintan's name has strong association with the priestly, sacred class in many Indo-European traditions and is associated with druids' and filid's names in Irish material, see for example: Find Fili, Finnachta mac Ollamon, Findoll, Laidcenn ('snowhead') (Kalygin 2003: 94-95; DIL s.v. ladg). Moreover the colour has certain associations with vision and knowledge as the Common Celtic nominal base *vindo- 'white' derives from the IE root *ueid- 'to see (clearly), to know' with nasal infix (Delamarre 2003: 321; Kalygin 2002: 110). On the basis of these associations V. Kalygin takes Fintan to be one of the numerous personifications and late transformations of an archaic deity Find who possesses and imposes hidden knowledge (Kalygin 2002: 110). We shall try to show that the nature of Fintan mac Bóchra is more complex.

Material concerning Fintan in Early Irish literature appears to be divided into several compact sub-stories; although belonging to the same tradition, each of these is self-sufficient and functions as a plot on its own. The earliest surviving variant of his story occurs in the Old Irish tale Airne Fingein ('Fíngen's Night-Watch'), assigned by Vendryes to the ninth or tenth century. Here Fintan figures as one of the buada ('wonders, gifts') attending the birth of the future king Conn Cétchathach; even if these two mythological characters are not otherwise associated with each other, all of Fintan's qualities as a renowned sage and a keeper of tradition are somehow dependant on this event. The tale of Fintan's wonderful 'transformation' is related to Fíngen by the fairy woman Rothníam:

'Ocus cid búaid n-aile, a ben ?' or Fingen. 'Ní hansa,' or in ben, '.i. Finntan mac Bochra maic Ethiar maic Ruaill maic Amda maic Caim maic Nóe ro ír Día dó, in Rí úasal, conid ard-brithem in chentair im ecna. $\rceil$ atá i n-amlabrai (.i. nírbó maith a erlabra ce ro boí oca) ón uair ro cúala tonngar na dílenn fri tóib slébe Oilifet, 7 
sé for Tul Tunne i n-íarthardeisciurt Éirenn. Arróegraind a urlabra \urcorner forrálaig co r-rabi i n-a chotlud céin boí in díliu forsin bith, $\urcorner$ atá cen sholabra ó sin ille cosinnocht $;\rceil$ forralgadh fírinne Éirenn $\rceil$ a coimhghne $\urcorner$ a fáitsine $\urcorner$ a senchus $\urcorner$ a dligeda córa cusanocht. Fo dháigh is é óenfher firén forfhácaib in díliu dia héis. Is innocht dorroíded (.i. ro foíded) ón Choimdid spirut saineamail faitsine i rricht máeth-óclaíg, co n-ecmaing builliu i n-a béolu di gaí gréine, co r-raibe tria chlais a dá chúlad, co fil secht slabraid nó secht solabra filed for a $\mathrm{t}[\mathrm{h}] \mathrm{engaid}$ iar sin. Corub anocht ra foillsiged senchus 7 coimgne. Conid de asbreth "ferr tui báethlabrai", (Vendryes 1953: 5-7). ${ }^{4}$

"And what other gift, o woman?" said Fingen. "Not hard," said the woman. "i.e. Finntan, son of Bochra, son of Ethiar, son of Ruall, son of Amda, son of Ham, son of Noah, God, the High King granted him that he became a chief judge in this world as for his wisdom. And he is mute (i.e. his speech was not good although he could speak) from the time that he heard the wave-roar of the Flood against the side of Mt. Olivet, while he was on Tul Tuinde in the Southwest of Ireland. His speech was taken away from him and he has hidden himself and was asleep as long as the Flood was upon the world, and he was without good speech from that time onward until tonight; and the truth of Ireland, her inherited knowledge, her prophecy, her tradition, her just laws were hidden until tonight. For he is the only righteous man that the Flood left behind it. Tonight a beautiful spirit of prophecy in the shape of a gentle youth has been sent from the Lord, and a ray of the sun hits Fintan in his lips and it has extended through the trench of the back of his neck so that there are seven chains or seven good speeches of filid on his tongue since that time. And tonight the tradition and inherited knowledge was revealed. So that it was told 'silence is better than foolish speech".

Before commenting on this passage from $A F$ it is worth mentioning $\mathrm{H}$. Meroney's suggestions in his review of J. Vendryes' edition of the text. Meroney seems to take Fíngen and Fintan as functionally one and the same character and derives Fíngen's name from *Vindo-genos (Meroney 1953-58: 247). A more reliable basis for associating these characters,

\footnotetext{
${ }^{4}$ I established my edition of the passage on the basis of the four MSS in which the tale is contained (Book of Fermoy (A), Liber Flavus Fergusiorum (B), D IV 2 (D), and Book of Lismore (L)) and thus it differs from the Vendryes's edition. For variae lectiones, see Appendix. Emphasis in original text and in translation is mine.
} 
apart from a presumed onomastic similarity, is that it is Fintan who enumerates the wonders of Conn's birth in the Dinnshenchas of Temair Lúachra (Gwynn 1991: 238). These associations seem to be too far fetched, effective only at the level of $A F$ and its plot, given that different etymologies as well as different roles played by these two protagonists are rather obvious. Note also a consistency in spelling of Fintan's name in $A F$ - Findtan (D), Finntan (L), Findtan (A), Finntán (B) - which seems to point to a formation different from O.Ir. Finten.

Fintan's genealogy from Ethiar to Noah is omitted in D and L. If we accept the original form mac Bochra, we can take his genealogy as the interpolation intended to link antediluvian Fintan with Noah and Old Testament tradition. The late nature of this interpolation where Bochra is taken as Fintan's father's name is supported by the fact that Bochra is attested as a female name applied to a mother of three saints in the genealogies (Ó Riain 1985: 722.36).

It is significant that Fintan is called here a 'chief judge' (ardbrithem), which corresponds to the highest known status of judges in Ireland (Kelly 1991: 52). Fintan's acquired status seems to be even more important when we meet Samuel the prophet - the last of the judges of Israel - giving Fintan his speech and memory (?) a few lines below.

\section{Mount Olivet and Samuel the prophet}

In the passage discussed we encounter a unique account of Fintan's escape from the Flood, which corresponds to the $L G$ version only insofar as it makes the old sage the only person in Ireland to have survived the Deluge. Fintan became mute from the shock he experienced at hearing the wave-roar of the Flood at the side of what is called mount Oilifet. J. Vendryes, Ch.-J. Guyonvarc'h, and S. Shkunaev left the meaning and significance of this place-name unexplained in their commentaries on the passage (Vendryes 1953: 36-37; Guyonvarc'h 1980: 197; Shkunaev 1991: 146). It is only in T. P. Cross and A. C. L. Brown's translation of $A F$ that they have rendered this place name correctly as Mount Olivet (Mount of Olives), although they did not comment on this rather strange location (Cross \& Brown 1918: 36). Slíab Oilifet is definitely the same as 'Mount Olivet' from King James Bible, in later translations of the Bible called the Mount of Olives. Mount of Olives is situated on the heights east of Jerusalem and is separated from the Temple Mountain by the Kidron Valley. It is rarely mentioned in the Old Testament and is mostly associated with the closing years of the life of Jesus Christ. Both Old Irish 
Oilifet and English Olivet derive from Latin Olivetum 'olive grove' (Hastings 1963: 711). ${ }^{5}$

What is the significance of Mount Olivet here, if any? It has evidently no connotations with the Flood in the Bible and could have been introduced just due to its New Testament role. Nevertheless we note that the Mount of Olives first appears in the Old Testament in II Samuel (II Reg.) 15.30 when King David, anointed by Samuel, went up the mountain symbolising his descendant's future ascension. The action takes place after the death of Samuel the prophet, who also appears in our passage; but still its account is given in the Second Book of Samuel and is associated with the king chosen by Samuel. This is probably the reason for Mount Olivet and Samuel the prophet figuring in the same account.

Another possible clue to the role of the Mount of Olives in our passage, its association with the Deluge and the universal catastrophe, lies in Old Testament eschatology (Zechariah 14.4-21). According to Zechariah it is from Mount Olivet that Doomsday shall begin: 'And his feet shall stand in that day upon the mount of Olives, which is before Jerusalem on the east, and the mount of Olives shall cleave in the midst thereof toward the east and toward the west, and there shall be a very great valley'. Especially important is the description of an eschatological flood when 'living waters shall go out from Jerusalem' (sic!) (Zech. 14.8; et erit in die illa exibunt aquae vivae de Hierusalem, Vulgate). It seems that in the Irish text, evidently much influenced by the Old Testament, time is concatenated, and the primordial Deluge shows qualities of the eschatological one.

There are further Old Testament motifs and borrowings in our passage. According to A and B the spirit of Samuel the prophet makes his appearance before Fintan in the shape of a gentle youth. The image of Samuel's spirit is taken from a well-known episode in I Samuel (I Reg.) 28.11-13 when the spirit of Samuel appears before King Saul and denies God's help to him. The author/redactor of $A F$ obviously has not meant this episode when introducing Samuel's spirit in his account. It is just the idea that Samuel's spirit is known from the scriptures, which made the plot to take this form. The image of Samuel's spirit was well known among early Irish monastic literati. One early example of this image's use as a topos is found in the work of Augustinus Hibernicus 'On the Miracles of the Holy Scripture' (De mirabilibus Sacrae Scripturce) written in the year 655 in the monastery of Lismore. The author compares Elijah's appearance beside Christ on the Mount of Olives to the apparition of Samuel and ponders on the nature of this vision: 'or did he (Elijah -

${ }^{5}$ Cf. eclas na fresgabála ('church of Ascension') on top of Sliabh n-Olifet (Leabhar Brecc 158). 
G.B.) put on an illusory semblance taken from the air, as Samuel was seen?' (an ex aere simulatum, sicut Samuel visus est, habitum fingebat?, Migne 1841: 2198; Carey 1998: 71). This gives us an idea how Samuel's spirit was perceived and what functions it might acquire in Early Irish monastic circles.

Nevertheless a reading peculiar to A and B cannot be part of the original text, a principle which I have followed above when treating words and phrases found only in those two MSS as later insertions. Also neither $\mathrm{L}$ nor $\mathrm{D}$ with their different readings can preserve the original reading here. We only tentatively reconstruct saineamail faitsine based on saineamail faisdine in $\mathrm{D}$. As advised by $\mathrm{J}$. Carey it seems that the $\mathrm{AB}$ reading goes back to an incorrect expansion, with minim confusion, of sain-fáth-. The spirit of prophecy possibly represents here a more native phenomenon, similar to 'the spirit of wisdom/poetry' attested also in Cormac's Glossary and in Cóir Anmann (Meyer 1912: 94). Samuel's introduction on the whole still seems to be justified by the pre-existing exegetical tradition.

\section{The spear of the sun}

After Samuel's spirit had descended in the shape of the youth the narrative of $A F$ turns to another feature and describes as if it were the revelation proper. Fintan's lips are hit by a ray of the sun (co n-ecmaing builliu i $n$-a béolu di gaí gréine, co r-raibe tria chlais a dá chúlad, lit. 'so that a blow from a ray of the sun strikes into his mouth and it (a ray - G.B.) was through the trench of his neck'). The expression gáe gréine deserves further discussion. It is obviously a fixed expression meaning 'a ray of the sun'. At the same time one has to stress that it literally means 'a spear of the sun'. I cannot find any other example in Early Irish literature where the literal meaning is so close to the semantics of the expression as in our example from $A F$. It looks as if the spear of the solar substance has extended from Fintan's mouth to the back part of his neck. And then speech, memory, and knowledge are manifested.

The notion of knowledge revealed by the sun is a common feature for early Irish thought and seems to have certain native elements in its origin. Nevertheless, as noticed by J. Carey (1999: 34), this image appears also in the hagiography evidently borrowed from the Continental ecclesiastical sources. In his Life of St. Columba, Adomnán ascribes to the saint thoughts on the nature of revelation to the chosen ones:

Totum totius terrae orbem, cum ambitu ociani et caeli, uno eodemque momento quasi sub uno solis radio, mirabiliter laxato mentis sinu, clare et manifestissime speculentur, 
The mind's limits being miraculously loosened, they clearly and most plainly behold the whole of the earth, together with the circuit of the ocean and the heavens, in one single moment, as if beneath a single ray of the sun.

(Anderson 1991: I.43, 78) ${ }^{6}$

The immediate source of this image is to be found in the Dialogues of Gregory the Great (540?-604) as first shown by G. Brüning (1917: 250). Almost identical expressions deal here with the same matter of revelation to the chosen ones and their universal perception afterwards: omnis etiam mundus velut sub uno solis radio collectus, ante oculos eius adductus est...quia ipse luce visionis intimae mentis laxatur sinus... (II.35); Qui..., mentis laxato sinu, quasi sub uno solis radio cunctum in suis oculis collectum mundum vidit (IV.8) (De Voguié \& Antin 1979: 238, 240; 1980: 42).

Here we encounter a notion of revelation of the transcendent knowledge in a single moment which is familiar to the both Insular Celtic medieval literatures (cf. the story how Taliesin acquired his superior knowledge from the three drops of the marvellous cauldron (Ford 1992: 65-67)). This notion implies the potential existence of eternity in any single moment or place in the world, which needs only a special circumstance to become manifest (Carey 1999: 34-35). ${ }^{7}$ One has to be aware of the influence of Continental European Christian thought here, although there is probably not enough evidence that the meaning of gáe gréine has been borrowed. Semantic connotations attached to gáe gréine as a set phrase and its widespread use in Old and Middle Irish sources implies native origin. Cf. as Iwan Wmffre suggests, W. paladr 'spear, spear shaft' also meant '(sun's) ray', later, by the seventeenth century, in the same meaning of 'ray' the original $\mathrm{pl}$. form pelydr became a singular and a new plural pelydrau emerged.

It seems also that the revelation experienced after the influence of the gáe gréine is similar in nature to the phenomenon of imbus gréine 'the great knowledge of the sun' referring mostly to poetical inspiration and described in O'Davoren's glossary in the article on tascar (the language is late Middle Irish):

\footnotetext{
${ }^{6}$ The same description is found in the opening chapter of Vita Columbae: in aliquantis dialis gratiae speculationibus totum etiam mundum, veluti uno solis radio collectum, sinu mentis mirabiliter laxato, manifestatum perspiciens speculabatur (I, 1).

${ }^{7}$ J. Carey ponders here on the similar nature of the Irish Otherworld, the very title of his collection of essays A single ray of the sun owes to the above-mentioned quotation from Adomnán.
} 
imbus gréine .i. bolg greine imfuilnges in grian for na luibhibh 7 cidh be caithis iat bidh dan aigi (Stokes \& Meyer 1904: 477 § 1569).

Great knowledge of the sun i.e. the bubble of the sun which the sun produces on the herbs, and who consumes them will have a poetic gift.

The expression gáe gréine from our passage in its turn is used as a legal term in Irish laws. It is for some reason mentioned in the 'sequel' to Críth Gablach as a term for one of the lower classes in Early Irish society, aithech baitse, who is called gáe gréine because of his light legal rights (Laws IV 352). ${ }^{8}$

As J. Carey informs me, the ray that goes to the back of Fintan's head may be connected with the statement in Cath Maighe Rath that it was specifically the loss of his inchinn cúil 'back brain' which gave Cenn Faelad his powers of heightened remembrance (O'Donovan 1842: 282.6). This in turn is probably to be associated with the view in traditional psychology/physiology that memory is located at the back of the head (see also a passage from Bretha Déin Chécht in the section below).

\section{Seven chains, seven eloquences}

The gift was revealed and Fintan received seven chains on his tongue. Only two manuscripts speak of secht slabraid (A and B); D and L mention only secht solabra 'seven eloquences'. Taking stemmatic considerations into account only it may seem that secht slabraid is a later explanation of secht solabra, which has appeared due to phonetic resemblance. The image of the seven chains, notwithstanding their apparent later insertion, was commented upon by J. Vendryes and Ch.-J. Guyonvarc'h, who recalled the description of Celtic Hercules, or Ogmios, in the short text by Lucian 'Heracles', which was probably written down on the basis of recollections of his visit to the Rhône valley (Vendryes 1953: 39; Guyonvarc'h 1980: 198). There are several striking features that remind us of Lucian's description (second century AD) and not only the chains. Lucian starts with a Celtic (Gaulish) name for Heracles, Ogmios, and describes his appearance on a certain painting (which would be quite unusual for a Celtic image): 'he is extremely old, bald-headed, except for a few lingering hairs which are quite grey,... and he is burned as black as can be' (cf. *Vindo-senos 'weiss(haarig) und alt'). Then follows a description of golden and amber chains attached to the tip of his tongue, it is with these chains that Ogmios drags a great crowd of men 'who are all

\footnotetext{
${ }^{8}$ I mean here only that the ray of the sun is a very light and subtle substance.
} 
tethered by the ears'. Somehow unnaturally a Celt at Lucian's elbow explains to him the meaning of the image (F. Le Roux (1960: 211) has argued that this Celt might have been a druid, as he is called by Lucian a $\varphi \imath \lambda o ́ \sigma o \varphi о \varsigma)$. Ogmios, he says, is represented as an old man, 'for eloquence and eloquence alone is wont to show its full vigour in old age' (Harmon 1991: 62, 64, 66).

A rational explanation by a Celt might be no more than Lucian's own speculation, especially as Gaulish Ogmios is likely to be derived

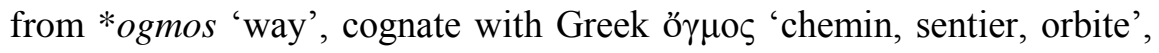
Skr. ajmah, and Ogmios seems to have the qualities of a 'leader' rather than an 'orator' (Delamarre 2003: 238; Kalygin 2006: 127). At the same time the image of eloquence connected with chains and old age seems to be relevant to Fintan's description. One of course cannot equate Fintan with Gaulish Ogmios or Irish Ogma (especially given that these theonyms have different linguistic and mythological background). On the one hand, Fintan might have acquired here some features of a different mythological character, on the other as a primordial man he has to show features of a cultural hero, as a man first in eloquence and persuasion (although we are not sure whether Fintan's chains were tied to any human beings).

Early Irish literature supplies another parallel both to Lucian's Ogmios and to Fintan's image in $A F$. The Stowe version of the Táin preserved a remarkable passage describing a black-haired man with chains from the troops of the Ulaid:

Fer dub dian temhnighe temerdha $i$ n-airenach na buidhne sin. Seacd slabhradha ima braghait, moirseser $i$ ccin cacha slabhraidh. Do srenga-som na secht moirseser sin co m-benann a srubha fri talmain, co tabrait athais fair, co fostann... Ercenn tri m-brugaid is é fil is na slabradaibh (Windisch 1905: 799, 801 (1. 5524-5531)).

A black, swift, dark man is in front of the host. There are seven chains around his neck and seven men at the end of each chain. $\mathrm{He}$ drags those seven times seven men so that their noses strike the earth, and they made reproaches to him, and he stops... Ercenn [son] of three hospitallers is the man with the chains.

This character possesses certain qualities similar to Ogmios (Heracles) such as his black colour, chains attached to him and his strength. At the same time the black man has seven chains around his neck and is surrounded by sevens, in a manner recalling Fintan. Ercenn might be seen as a figure comprising features of Ogmios and Fintan, as a necessary bridge between them, supporting Ogmios' relevance in the analysis of the 
Fintan material (as discussed with I. Wmffre, there is also a possibility that Ercenn derives from Heracles; for weakening of suffix consonantism, cf. Sechnall from Secundinus). One important feature though is missing, namely eloquence. Ercenn is shown as a conductor, perhaps as a psychopomp dragging suffering souls to the abode of the dead? Fintan's image lacks these connotations, and one has to stress that both $A F$ and $T B C$ accounts represent mere distorted reminiscences of the former relevant religious idea (in case we assume that this idea existed in an unique and canonical form).

One has to bear in mind when encountering the sevens in Fintan's passage from $A F$ that the importance of this number here may be due both to native and ecclesiastical sources. There is no need further to underline the significance of the number seven in Insular Celtic traditions; it is sufficient to mention the Rees brothers' statement that this odd number makes the even number (six) full as in mórseser 'great hexad' (Rees 1973: 201). A specific example of this Irish preoccupation with sevens is found in the eighth century Irish 'Chant of long life' (Cétnad n-Aise), where we encounter 'seven daughters of the sea', 'seven waves', 'seven ages', 'seven candles'. At the same time commenting on this syncretic composition J. Carey suggests an implicit association between the sevens in the poem and the seven gifts of the Holy Spirit 'derived by the Fathers of the Church' from the Vulgate text of Isaiah 11:2, while other Irish texts speak of the 'seven-formed Spirit' (Spirut sechtndelbach) (Carey 1998: 138). ${ }^{9}$ It seems likely that along with native element in the story of Fintan's revelation one can allow Christian reading of the same text. The seven chains then can be explained as seven gifts from the Holy Spirit (the same qualities mentioned in Isaiah), especially when Samuel's spirit (or spirut saineamail 'excellent spirit' in D and L) plays an important role in the revelation. There might have been associations with Pentecost as well in terms of acquiring eloquence as a gift from the Holy Spirit. Moreover the theme of a divine gift is expressed in the beginning of the passage (ro ir in Rí úasal).

secht solabra (filed - D) 'seven eloquences (of poets)' is supported by the testimony of other traditional Irish texts. Caílte, one of the main characters and storytellers in the twelfth century Acallam na Senórach ('The Colloquy of the Elders'), exaggerates and expresses his wish operating with the same heptads: 'were there seven tongues in my head, and seven eloquences of the sages in each tongue' (uair da mbeitís secht

\footnotetext{
${ }^{9}$ Isaiah 11:2: 'And the Spirit of the Lord shall rest upon him, the Spirit of wisdom and understanding, the Spirit of counsel and might, the Spirit of knowledge and of the fear of the Lord'.
} 
tengtha im cind $\urcorner$ secht solabarta súadh cecha tengad dib) (Stokes \& Windisch 1900: 1. 7551).

The most archaic level of the passage from $A F$ together with the $L G$ evidence of Fintan's sleep in the cave on Tul Tuinde is likely, as will be shown below, to be linked to a pre-Christian initiation ritual. The hollow of the neck (clais da chulad) is mentioned among the 'twelve doors of the soul (or of life)' (da dorus .x. anma) in the eighth-century law tract Bretha Déin Chécht (Binchy 1966: §2A). Physiologically the back of the neck is a fragile spot: a severe blow on which might break the first two bones of the neck and cause death. It is not surprising that this spot is specifically mentioned in Fintan's account.

A striking parallel (and such remote parallels are always striking for a modern scholar) to this type of ritual is found among the Aranda (Arunta) of Central Australia. This people knew one particular way of making a professional medicine man by the Iruntarinia, or 'spirits'. The candidate goes to the mouth of a cave and falls asleep. At the break of day (at the sunrise), one of the Iruntarinia comes and throws an invisible lance at him, which pierces the neck from behind, passes through the tongue, making a large hole in it, and then comes out through the mouth. The candidate's tongue remains perforated; one can easily put one's little finger through it (Spencer \& Gillen 1969: 522-524). It is in a similar way that Fintan of our story becomes a professional judge.

\section{The keeper of tradition}

Fintan's revelation as described in $A F$ is closely connected with the manifestation of the history (coimgne 'synchronism'), laws and 'truth' of Ireland. Ireland as it were comes into history from the primordial chaos thanks to Fintan's memory. The ages of her settlers, rulers and warriors appear at once at the birth of the great king and at the time of the revelation to an ancient dumb witness (which is not a contradiction in itself). This cosmological myth refers to a transition from pre-written traditional culture to a new written Christian culture with its deep Classical roots and historical consciousness: from the time when the tradition was hidden to the period of its revelation and fixation. This is another function, which is very important for the understanding of Fintan and his myth in early Irish literature.

The manuscript tradition differs as to what disciplines were manifested within Fintan: the tradition here seems to be less sure (Vendryes 1953: 38). The Book of Lismore gives the reading: forralgadh firinne Éirenn $\rceil$ a coimhghne $\rceil$ a fáitsine $\rceil$ a senchus $\rceil$ a dligeda córa cusanocht ('the truth of Ireland, her history, her prophecy, her tradition, her just laws were hidden until tonight (the night of Conn's birth)'). This 
phrase is found only in one manuscript containing $A F$ (L, fo. 138a, 11. 2931). As J. Vendryes (1953: 38) has pointed out, this can be regarded as a secondary addition to the original text, while the earlier version of D IV 2 merely underlines the fact that the senchus of Ireland was revealed. On the one hand this addition aims to confirm Conn's position as a firfhlaith and develops the cosmogonic qualities of his birth up to the highest level - the truth is manifested only with the birth of an ideal 'true king'. On the other hand, these disciplines/qualities correspond to Fintan's role as a keeper of historical, legal and moral (firinne) tradition, no matter how recent or synthetic this role might have been.

In this capacity Fintan is known to an early Middle Irish text contained in Lebor na hUidre - an apocryphal unfinished account entitled Cethri arda in domain ('Four cardinal points of the world') on the four wise men who kept historical knowledge after the Flood in the four quarters of the world; its variant of Fintan's story is later than $A F$ 's (pf. 3 sg. ro chomét of Mid. Ir. coimétaid 'keeps' instead of OIr. pf. 3 sg. con-roiter of con-ố), and it is evidently more 'learned' and also pays much attention to Fintan's historical knowledge. I supply here a text from $L U$ with my translation:

CETHRI arda in domain .i. tair $\urcorner$ tíar tess $\urcorner$ túaid. Bátar dano cethror intib .i. fer cech arda 7 is do mórad adamra 7 mírbaili dorigni Dia sin .i. d'innisin senchasa $\urcorner$ inganta in betha so sil Ádaim.

Fintan mac Bócra meic Lamíach (t Fintan mac Libi meic Lamiach $)^{10}$ (t Fintan mac Bóchrai meic Ethiair meic Púail meic Airrda meic Caim meic Noe) ${ }^{11}$ is é in tres fer tánic i nErind ría ndilind is eside ro chomét senchasa íarthair in betha .i. i nEspáin $\urcorner$ i nErind $\urcorner$ in cach conair dodeochatár Góedil archena .l. bliadna re ndílind $\urcorner$.u. c. $\urcorner$ u. m bliadna íar ndilind a aes co n-erbailt ac Dún Tulcha (LU 10063-10071).

FOUR cardinal points of the world i.e. East and West, South and North. There were four men in them; i.e. a man in each cardinal point and it is to magnify wonders and miracles that God did that, i.e. to tell the traditions and wonders of the world to the seed of Adam.

Fintan, son of Bócra, son of Lamech or Fintan, son of Libi, son of Lamech or Fintan, son of Bóchra, son of Ethiair, son of Púal, son of Airrda, son of Ham, son of Noah. He is one of the three men who

\footnotetext{
${ }^{10} \mathrm{M}=$ Mael Muire.

${ }^{11}$ Interpolator $\mathrm{H}$.
} 
came to Ireland before the Flood, it is he who kept the traditions of the West of the world i.e. in Spain and in Ireland and in every way that the Gaels went besides that. Fifty years before the Flood and five hundred and five thousand years after the Flood: that was his age when he died at Dún Tulcha.

Then follows a short account of three other keepers of tradition in the other cardinal points of the world. The LU version of Fintan's story supports LG's account of the three first men in Ireland before the Flood (in the legends of both of Banba and Cessair). In a characteristic learned manner Cethri arda in domain extends Fintan's prerogatives to the whole West. A specific feature is also the inclusion of Gaels into Fintan's myth although Fintan is never associated with this group in other sources. LU's account is evidently a learned apocryphal composition created in monastic circles. Nevertheless, Fintan's figure implies that the whole composition might have been written in order to justify Fintan's unique role in Irish tradition, to make his mission universal. Fintan is counted among the divine mirabilia. His supernaturally long life is mentioned in the text but the shape-shifting motif is left untouched (as well as in $A F$ ). We have traces of Fintan's shape-shifting motif attested in the early Irish poem 'The Colloquy between Fintan and the Hawk of Achill' written by an unknown cleric (Meyer 1907: 24-39). The dialogue is taken place between two most ancient creatures in Ireland (and consequently in the world). They relate to each other histories of their lives and the chronology of events in Ireland. It is significant that this poem mentions Fintan's transformations (or rebirths?) first into salmon, and then into eagle (ilar) and hawk (sebac) (Suidigid Teglach Temra also admits his transformations). The latter two birds are often interchangeable in Irish accounts on the most ancient creatures and consequently we are left with the same pair: the salmon and the hawk - the fish and the bird. In this way one can read the poem as a dialogue of Fintan with himself or with his other shape. Fintan is called here by the hawk 'the poet, and the prophet' (in fili 'san fáidh), which reminds Tuán's characteristic as fáith and is later supported by other sources. The text gives another version of Fintan's fate after the Deluge and the death of Cessair, Bith, Ladra, and Illann, son of Fintan (thus the author is well aware of Cessair's legend). This version does not include any apocryphal biblical narrative unlike $A F$ and is based upon some well-known archaic (local?) beliefs. The Hawk of Achill asks Fintan: 'Tell us now without delay/ The evils and wonders that befell you' (innis dúinn gan chairde anuis/ na h-uilc is aidhble fúaruis). Fintan answers: 'At the black out-pouring of the Flood, /The Lord put me, to my misery/ Into the shape of a salmon at every spring' (ar $n$ - 
dubhdortadh don dílinn/ rom-chuir in Coimdhe dom chrádh/ h-i richt égne ar gach n-úaran) (Meyer 1907: 26). Thus Fintan here escapes the Flood by transformation into a water creature rather than by surviving under ground. The poem 'Temair I' from the metrical Dindshenchas is attributed to Fintan, who concludes verses calling himself 'a salmon not of one stream' (Is mise Fintan fili, nirsam écne óen-lindi) (Gwynn 1903: 4.41). Rather than taking écne symbolically as E. Gwynn one has to reconsider this image in the broader context of the myths discussed.

Finally, Cethri arda in domain is the first early Irish text that mentions his death at Dún Tulcha at Kenmare Bay in the Southwest of co. Kerry and correspondingly in the Southwest of Ireland. This direction corresponds to $A F$ 's account of Fintan's whereabouts after the Flood (sé for Tul Tunne $i$-íarthardeisciurt Éirenn). The close correspondence between Dún Tulcha and Tul Tuinde seems evident enough, although if we follow Vendryes' reading of for tul as a complex preposition it makes Dún Tulcha attached to our protagonist at a much later date. The Rees brothers have discussed the quality of West Munster in early Irish imago mundi and pointed out to its significance as the primeval world, the place of origin (Rees 1973: 135). Fintan's example (of the flood-myth hero and the keeper of tradition) fits in their scheme as well especially bearing in mind that Tul Tuinde also belonged to West Munster, according to the Fir Bolg division of Ireland.

It is to keep the tradition or ancient lore (senchas) that Fintan is left alive by God. The D IV 2 variant of $A F$ also makes senchas the only important matter or discipline to be guarded by the antediluvian wise man. The specific Irish term senchas can hardly be translated as a mere 'history'; it is rather connected with the ancient sacred events, laws (Senchas Már) or institutions given once and for ages (see Mac Cana 2011: 54-55). Thus the situation described both in Cethri arda in domain and in D IV 2 reflects a transitional stage between pre-written culture with its revered and eternal senchas and new Christian historical consciousness with its sacred history and linear concept of time. The method of the "restoration" of ancient historical knowledge by revelation can be easily demonstrated in the legends of "finding" such as the Dindshenchas (placelore) found by Amorgen the fili or the Táin ("The Cattle-Raid of Cuailnge") found by Muirgen the fili (Stokes 1894: 277; Best \& O’Brien 1967: 1119 (f. 245b)). It is also important with regard to the Dindshenchas that it is Fintan mac Bóchra who reveals the hidden place-lore of Ireland to Amorgen, Diarmait's chief poet.

The early Modern Irish tale 'The adventures of Léithin' influenced by earlier 'Fintan and the Hawk of Achill' is another Irish text, which reproduces the scheme of Cethri arda in domain. The magic one-eyed 
salmon $(\mathrm{Goll})$ tells the story of the four men who survived the Flood, one of whom was Fintan. He ascribes this story to wise men (áirmhíd eoluigh) and makes Fintan the keeper of kin-group descent (cineól) and genealogies (Hyde 1914-1916: 141). Nevertheless this late account proves that LU tradition of Fintan retained its relevance in the learned Irish milieu through the centuries.

It is interesting that the notes by Meredith Hanmer, the late sixteenth century antiquary, give a later and distinct variant of the story of the four antediluvians. In these notes Fintan is said to have been transformed into different forms and shapes (but only the salmon's shape is alluded to). Then we are told: 'The ... fower were transformed in fishes that could liue under the water, by the providence of God in the west, north, east, \& south' (Smith 1953-58: 212). This fish-transformation motif does not appear in any other Irish text on the four antediluvians and one might ascribe it to the influence of a well-known story about Fintan; on the other hand, given that the variant of Cethri arda in domain in LU, the earliest manuscript, has lost its ending, one cannot be sure concerning its fuller content.

G. Keating, writing even later than M. Hanmer, is well aware of the four antediluvians but as a scholar familiar with modern historiographic methods is very sceptical about them. He cites a poem on this matter but stresses that their existence contradicts the Old Testament and the story of Noah (Keating 1902: 148).

Early Irish literati were less preoccupied with such contradictions, especially if they placed their country outside of the confines of the outer world. The Edinburgh Dindshenchas of Slíab Betha contain another possible explanation to the story of the four antediluvians from LU. It refers to four protagonists (Bith, Cessair, Ladru and Fintan) only without any mention of Cessair's women. The Flood drowned these four 'as it overtook them at each point' (ros-baidh in dili amail dos-tarraidh in gach aird). Now the action takes place in Ireland and these 'heights' or 'points' correspond to the well-known heights in different provinces of Ireland, the island being a world on its own (macrocosm, see Mac Cana 2011: 70). Then follows the standard information that Fintan survived the Flood and delivered knowledge to the following generations: 'he was for a whole year drowned, so that it was he then who entrusted us (?) again' (robi bliadan lan $i$ mbadhud conid iarum ron-athnai arisi) (Stokes 1893: 59). It is tempting to see traces of a native myth in this story from the Dindshenchas, a myth of the four Irish antediluvians surviving at four cardinal points of Ireland that gave grounds for a learned universal version of the same myth. 
It seems that the four antediluvians fitted well into the archaic scheme of the world division. The four quarters of the world are important directions both in medieval European cosmography and in the Irish perception of space. One might assume that the whole story in LU was invented in order to fit the myth of the four antediluvians' wonderful survival into the framework of Biblical and universal history.

Queen's University Belfast

\section{References}

Anderson, A.O. \& M.O., eds., 1991, Adomnán's Life of Columba, Oxford: Oxford University Press.

Best, R. I. \& O'Brien, M., eds., 1967, The Book of Leinster. Vol. 5. Dublin: Dublin Institute for Advanced Studies.

Binchy, D. A., ed., 1966, 'Bretha Déin Chécht', Ériu 20, 1-66.

Bromwich, R., ed., 2006, Trioedd Ynys Prydein (Third Edition), Cardiff: University of Wales Press.

Brüning, G., 1917, 'Adamnans Vita Columbae und ihre Ableitungen', ZCP 11, 213-304.

Carey, J., 1998, King of Mysteries. Early Irish Religious Writings, Dublin: Four Courts.

Carey, J., 1999, A Single Ray of the Sun. Religious Speculation in Early Ireland, Andover \& Aberystwyth: Celtic Studies Publications, Inc.

Cross, T.P., \& Brown, A.C.L., 1918, 'Fingen's Night-Watch (Airne Fingein)', The Romanic Review 9, 29-47.

Delamarre, X., 2003, Dictionnaire de la langue gauloise, Paris: Errance.

De Vogüé, A. \& Antin, P., eds., 1979-1980, Grégoire le Grand, Dialogues, T. 2, 3. Paris: Éditions du Cerf.

Ford, P., 1992, Ystoria Taliesin, Cardiff: University of Wales Press.

Guyonvarc'h, Ch.-J., 1980, Textes mythologiques irlandais I, Vol. 1, Rennes: Ogam - Celticum.

Guyonvarc'h, Ch.-J. \& Le Roux, F., 2005, Les druides, Rennes: Éditions Ouest-France.

Gwynn, E., ed., 1903, The Metrical Dindshenchas, Part I, Dublin: RIA.

Gwynn, E., ed., 1991, The Metrical Dindshenchas, Part III, Dublin: Dublin Institute for Advanced Studies.

Harmon, A. M., ed., 1991, Lucian, vol. I, Cambridge, Mass.; London: William Heinemann Ltd., Harvard University Press.

Hastings, J., 1963, Dictionary of the Bible, Edinburgh: T. \& T. Clark. 
Hyde, D., 1914-1916, 'The Adventures of Léithin', The Celtic Review, 10, 116-143.

Kalygin, V. P. 2002, 'Kel'tskaya kosmologiya' ['Celtic Cosmology'], in: Mikhaylova, T.A.. Kalygin V. P. \& Toporova T.V., eds., Predstavleniya o smerti i lokalizatsiya inogo mira u kel'tov i germantsev [Images of Death and Localisation of the Otherworld in Celtic and Germanic Traditions], Moscow: Yazyki slavyanskoy kul'tury, 82-109.

Kalygin, V. P., 2003, Yazyk drevneyshey irlandskoy poezii [Language of the Archaic Irish Poetry], Moscow: URSS.

Kalygin, V. P., 2006, Etimologicheskiy slovar' kel'tskih teonimov [Etymological Dictionary of Celtic Theonyms], Moscow: Nauka.

Keating, G., 1902, The History of Ireland, vol. 1, London: Irish Texts Society.

Kelly, F., 1991, A Guide to Early Irish Law, Dublin: Dublin Institute for Advanced Studies.

Le Roux, F., 1960, 'Le dieu celtique aux liens. De l'Ogmios de Lucien à l'Ogmios de Dürer', Ogam, 12, 209-34.

Mac Cana, P., 2011, The Cult of the Sacred Centre, Dublin: Dublin Institute for Advanced Studies.

McCone, K., 1991, Pagan Past and Christian Present in Early Irish Literature. Maynooth: An Sagart.

Mac Neill, E., 1981, Celtic Ireland. Dublin: The Academy Press.

Meroney, H., 1953-58, 'Review: Medieval and Modern Irish Series, Vols. XIV-XVII. Dublin: Institute for Advanced Studies, 1953-58', The Journal of Celtic Studies 2, 246-50.

Meyer, K., ed., 1907, Anecdota from Irish Manuscripts, vol. I. Halle, Dublin:

Meyer, K., 1912, 'Zur keltischen Wortkunde. I.', Sitzungsberichte der königlich preussischen Akademie der Wissenschaften, 790-803.

Migne, J. P., ed., 1841, Patrologiae cursus completus. Series Latina. Tomus 35, Paris.

O'Donovan, J., ed., 1842, The Banquet of Dun na n-Gedh and The Battle of Magh Rath, Dublin: The Irish Archaeological Society.

O'Rahilly, T.F., 1946, Early Irish History and Mythology, Dublin: Dublin Institute for Advanced Studies.

Ó Riain, P., 1985, Corpus genealogiarum sanctorum Hiberniae, Dublin: Dublin Institute for Advanced Studies.

Rees, A. \& B., 1973, Celtic Heritage, London: Thames and Hudson.

Shkunaev, S., 1991, Predaniya i mify srednevekovoy Irlandii [Tales and Myths of Medieval Ireland], Moscow: Izdatel'stvo Moskovskogo universiteta. 
Smith, R.M. 1953-58, 'Meredith Hanmer and the Cesair Myth', The Journal of Celtic Studies 2, 207-13.

Spencer, B. \& Gillen, F.J., 1969, The Native Tribes of Central Australia, Oosterhout: Anthropological Publications.

Stokes, W., ed., 1893, The Edinburgh Dinnshenchas, London: D. Nutt.

Stokes, W., ed., 1894, 'The Prose Tales from the Rennes Dindshenchas', Revue celtique 15, 272-336, 418-84.

Stokes, W., \& Meyer, K., 1904, Archiv für celtische Lexikographie, vol. II, Halle: M. Niemeyer.

Stokes, W., \& Windisch, E., ed., 1900, Irische Texte, Series 4, Part 1, Leipzig: Verlag von S. Hirzel.

Vendryes, J., ed., 1953, Airne Fíngein, Dublin: Dublin Institute for Advanced Studies.

Windisch, E., ed., 1905, Die altirische Heldensage Táin Bó Cúalnge, Leipzig: Verlag von S. Hirzel.

\section{Appendix}

I established my edition of the passage on the basis of the four mss. containing the tale: Book of Fermoy (A), Liber Flavus Fergusiorum (B), D IV 2 (D), and Book of Lismore (L). The established text above is given by me on the basis of these variants and thus differ from Vendryes's edition.

Variae lectiones: 1. cid, ca D; cidh L. búaid, buaidh D; .b. L. n-aile, .ii. D; naili L. a ben, om. ABL. or Fingen, or Fingein D; for .f. L; for Fingin A; for Fingin B. or in ben, for in ben L; for in ben A; for in bean B. .i. Finntan, Findtan D; Finntan L; .i. Findtan A; i. Finntán B. mac Bochra, mac Bochrai D; mac Bochru B. 2. maic Ethiar. . maic Nóe, om. DL. Nóe, Noe A. ro ír, ro ir D; ro fir AB. diá dó, om. LAB. Rí, ri LB. uasal, huasal A; huasul B. conid, om. D ; conadh L. ard-brithem, airdbreathem $\mathrm{D}$; airdbreithemh L; ardbrithemh B. 3. in chentair im ecna, eccna in chentair $\mathrm{D}$; an cenntair im ecna $\mathrm{L}$; in centar im ecna $\mathrm{A}$; ín cenntar im ecna B. $7 a t a, 7$ ita $\mathrm{D}$; ata $\mathrm{AB}$; ár L. $i$ n-amlabrai, i namlabra D; om. L; ind amlabrai A. .i. nírbó ... oca, om. BD. nírbó, nir A. erlabra, herlabra A. ce ro, gia ro L. ita a n-amlabra, add. L. on uair, ond uair B. 4. ro cuala, rochuala $\mathrm{BL}$; atchualaidh D. tonngar, tondgur A ; todgur B. na dilenn, nan dileind $\mathrm{B}$; na dilind $\mathrm{D}$; na dilinn L. toib, taebh DL; toeb A. slébe, slebhe A; slebe B ; sleibi D ; sl-i L. Oilifet, Oilefet D ; Olofet AB. se, seissium fein D. for tul, ic tul AB. tunne, tuinne L; tunnei $\mathrm{B}$; tuindi D. $i$ n-iarthardeisciurt, i nd-iarthardeisciurt A ; a n- 
iarthardeiscert D ; i nd-iarthar thuaiscirt L; i n-iarthardesciurt B. Eirenn, na Herenn DA; na Herend B. 5. arroegraind . . rabi, is annsin bui D. arroegraind a urlabra, arroegl- in tonngharnadh L. forralaig, forral- L. co r-rabi, co raibhi L. i n-a chotlud, ina chodlud D; na codl- L; ina cotlud A; ina codlud B. cein, cen $\mathrm{AB}$. boi, bui $\mathrm{L}$; bói $\mathrm{B}$. in diliu, in dile $\mathrm{D}$, in dili $\mathrm{L}$; ín diliu A; in dilíu B. forsin bith, for bith $\mathrm{D}$; forsin mbith AL. ata cen sholabra . . córa cosinnocht, ata sin a socht o sin i leith 7 anocht ro hirslaicedh a irlabra dho do shlun[d]ud shenchusa Erenn, ar roboi a ndobur 7 i ndorcha in senchus sin gusanocht D. cen, gen L. 6. sin, sein A. ille, allé B. cosinnocht, cusanocht A; cusinnocht L. 7 forralgadh... córa cusanocht om. AB. 7. fo dhaigh, fo diaid AB. is e, iss e sin $\mathrm{D}$; iss e A. oenfher, enfher $\mathrm{D}$; æinfher L; oenfer A; oenfear B. firen, add. D. forfhacaib, forfaccaib D; forfacuib L; forfhacuib A; foracaib B. in diliu, in dile $\mathrm{D}$; dili L. dia heis, i n-Erinn $\mathrm{D}$; dia hes A. is innocht, cona[d] innocht $\mathrm{D}$; is anocht LA. 8. dorroided i. ro foided, rofuidhedh L ; rofaidhedh D; dorroided .i. dofuded A; dorroided .i. ro foideid B. on C[h]oimdid, om. D; on Coimdid L; on Coimdedh A. spirut, sbirut D; spirut L; in spirat A; in spirut B. saineamail faitsine, Samueil fatha $\mathrm{AB}$, shaineam- fhathacda $\mathrm{L}$; saineamail faisdine D. i r-richt máethóclaig, i richt mhaethoglaidh D; i rricht oclaig $\mathrm{A}$; i r-richt oclaid $\mathrm{B}$; i richd oclaigh L.9. n-ecmaing, $\mathrm{n}$ eacmuing D; n-ecmoing B; n-ecmhoing A. builliu, buliu B; builli L; om. D. i $n$-a beolu, i n-a bheolu LA. di gai, dia gai AB ; di ghai DL. corraibe, corraba AB; curaibhi L. tría chlais, tre chlais $\mathrm{D}$; tria clais LAB. a da chúlad, a chúlad A; a da cula B ; a chuil D; a dha chuladh L. fil, fuil A; fail B. secht slabraid nó om. DL. 10. secht solabra, uii. solabra L; secht solabrai A. filed add. D. thh]engaid, teangaid B. iar sin, fri slonnudh tshenchusa 7 comgne Erenn D. corub anocht . . . baethlabrai om. D. corub anocht ... coimgne om. AB. 11. conid de, conid e B. de asbreth, de $\sin$ L. ferr tuí, is ferr toi L; ferr tui A. baethlabrai, boethlabrai A ; baethlabra L; boethlobrai B. 